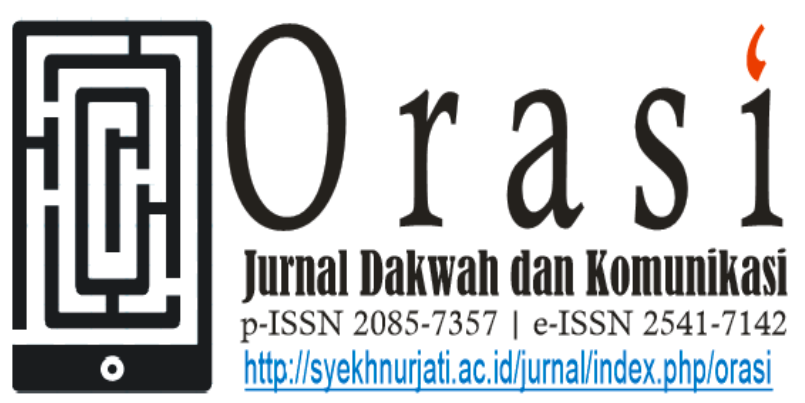

Volume 10 No. 2 Desember 2019

\title{
EKSISTENSI LPP RRI MATARAM BERDASARKAN TEORI NICHE
}

\section{EXISTENCE OF LPP RRI MATARAM BASED ON THE NICHE THEORY}

\author{
Andi Tamrin \\ Universitas Islam Negeri Sunan Kalijaga Yogyakarta \\ e-mail: anditamrin93@gmail.com
}

\begin{abstract}
ABSTRAK
Tingkat persaingan stasiun radio di NTB dalam beberapa kurun waktu terakhir ini cukup meningkat dengan hadirnya radio swasta. LPP RRI Mataran sebagai radio pemerintah, maka sudah sewajarnya harus bisa bersaing dan sekaligus menjaga eksistensinya sebagai lembaga penyiaran publik. Penelitian ini menggunakan metode penelitian kualitatif analisis diskriftif dengan mengunakan teori Niche. LPP RRI Mataram dapat bersaing, sekaligus dapat menjaga eksistensinya sebagai lembaga penyiaran publik dikarenakan dapat memenuhi tiga komponen besar untuk dapat bersaing dengan industri lainya. Tiga komponen tersebut adalah, capital, pengiklan yang dapat menunjang keberlangsungan hidup LPP RRI Mataram yaitu dari APBN dan APBD. types of conten, pro1, pro2, dan mengop timalkan sumber daya teknologi audio dan video streaming dan RRI Play, beyong. types of audience, yaitu seluruh masyarakat NTB.
\end{abstract}

Kata Kunci: LPP RRI Mataram, Eksistensi, Teori Niche

\begin{abstract}
The level of competition of radio stations in NTB in the past few years has increased considerably with the presence of private radio. LPP RRI Mataran as a government radio, so naturally it must be able to compete and at the same time maintain its existence as a public broadcasting institution. This research uses descriptive qualitative research methods. By using Niche theory, LPP RRI Mataram can compete, while at the same time being able to maintain its existence as a public broadcasting institution because it can fulfill three major components to be able to compete with other industries. The three components are capital, advertisers who can support the survival of LPP RRI Mataram, namely from the
\end{abstract}


state budget and regional budget. types of content, pro1, pro2, and optimize audio and video streaming technology resources and RRI Play, beyong. types of audience, the entire NTB community.

Keywords: LPP RRI Mataram, Existence, Niche Theory.

\section{Pendahuluan}

Perkembangan radio di Indonesia setelah merdeka, diawali dengan lahirnya Radio Republik Indonesia (disebut dengan istilah: RRI) pada tanggal 11 September 1945. RRI sebagai radio milik pemerintah memiliki fungsi dasar menyuarakan kepentingan pemerintah dan negara. RRI menciptakan sumpah pengabdian pada Negara dan bangsa Indonesia dengan Tri Prasetya RRI. Butir Tri Prasetya merefleksikan komitmen RRI untuk bersikap netral tidak memihak kepada salah satu aliran (keyakinan) partai atau golongan. ${ }^{1}$ Sejak awal berdirinya RRI memiliki peran sentral sebagai stablisator dan instrumen perekat Negara Kesatuan Rebuplik Indonesia.

Penyiaran di tanah air mengalami perkembangan yang sangat pesat setelah tahun 1998. Radio siaran berkembang jauh lebih pesat dibandikangkan masa-masa sebelumnya. Pada tahun 2002 setidaknya muncul 250 stasiun radio baru yang dikelolah individu atau kelompok, baik anggota PRSSNI sebagai organ tunggal perusahan radio pada masa Orde Baru, maupun organisasi baru seperti ARSSI (Asosiasi Radio Siaran Swasta Indonesia) atau ARI (Aliansi Radio Independen) jumlah ini belum termasuk RRI yang membuka layanan

${ }^{1}$ Muhamad Mufid, 2001. Komunikasi Regulasi \& Penyiaran diterbitkan Atas kerja Sama Dengan UIN Press), hlm. 37. frekuensi programnya 2-4 di hampir semua provinsi. $^{2}$

Tingkat persaingan stasiun radio di Nusa Tenggara Barat dalam kurun waktu terakhir cukup meningkat dengan hadirnya beberapa stasiun swasta. Jumlah stasiun radio, dan alat digital pun semakin moderen, mengharuskan pengelolah stasiun radio untuk dapat menyesuaikan diri dengan perkembangan teknologi. Jika radio tidak mengikuti perkembangan teknologi maka stasiun akan tidak mudah untuk bersaing dengan stasiun radio lainya. Radio hanya mempunyai kekuatan dengan suara, jika para pendengar radio tidak disuguhi dengan program-program yang menarik dan alat yang modern maka tidak mungkin pendengar akan mudah untuk memilih sesuai hati radio mana yang mereka inginkan.

Dalam pemahaman modern, pendengar radio bukan objek yang menggunakan telinga untuk menyimak sebuah acara. Mereka juga menggunakan nalar pikir dan sekaligus empati, sehingga membentuk sikap kritis. Jika yang ditayangkan oleh radio tidak sesuai, maka sikap mereka tidak hanya sekedar memindakan channel $^{3}$ atau gelombang

\footnotetext{
${ }^{2}$ Masduki, Radio Siaran dan Demokratisasi, (Yogyakarta: Jendelah, 2003), hlm. 7.

${ }^{3}$ Channel (gelombang) adalah jalur yang terdapat di mixer dan dapat dikontrol dengan menggunakan tombol Masduki, jurnalistik Radio,(Yogyakarta: Lkis, 2001), hlm. 126.
} 
ke stasiun lain. Tetapi mereka dapat bersikap antipati terhadap stasiun yang dinilai mengecewakan. Contohnya dominasi menu hiburan yang muncul di radio menimbulkan kebosanan jika tidak mampu menyuguhkan variasi program. Salah satu mungkin pertimbangan untuk memvariasikan program radio adalah sikap memperdayakan pendengar dengan memeberikan mereka suguhan yang bersifat aktual yang dapat mencerdaskan intelektual pendengernya. ${ }^{4}$

LPP RRI Mataram $^{5}$ merupakan lembaga penyiaran yang telah lama beroperasi dalam meberikan informasi, hiburan, pendidikan, dan perekat sosial kepada masyarakat Nusa Tenggara Barat dengan menggunakan frekuensi 89.2 FM untuk daerah Mataram dan sekitarnya dan 92.7 FM untuk luar kota Mataram, tidak pernah lekang oleh waktu hingga kini terus mengudara dengan memberikan informasi yang bermanfaat bagi pendengar Nusa Tenggara Barat. LPP RRI Mataram merupakan salah satu radio FM yang berada di Mataram dengan menyelanggarakan siaran dalam 2 programma yaitu: Pro1: Pusat siaran pemberdayaan pendengar. Pro2: Pusat siaran kreatifitas anak muda.

Selain LPP RRI Mataram masih banyak radio FM di Nusa Tenggara Barat yang masih beroperasai, tidak banyak dari mereka yang mengusung atau yang bertemakan radio berita, hiburan, pendidikan dan lain sebegainya. LPP RRI Mataram dengan

\footnotetext{
${ }^{4}$ Masduki, Jurnalistik Radio, (Yogyakarta: Lkis, 2001), hlm. 27.

${ }^{5}$ Lembaga Penyiaran Publik Radio Republik Indonesia Mataram.
}

berbasis memberikan pelayanan informasi, pendidikan, hiburan yang sehat, kontrol dan prekat sosial, serta melestarikan budaya bangsa untuk kepentingan seluruh lapisan masyarakat. Dan disisi lain masih banyak radio di Nusa Tenggara Barat Seperti radio Suara kota Mataram, radio Global FM Mataram, Dompu radio FM, Oisvira FM, radio Bima FM dan radio Gemini FM yang cendrungnya dengan saluran dangdut dan lain sebagainya yang berada di Nusa Tenggara Barat.

Lalu bagaiman LPP RRI Mataram Untuk mempertahankan eksistensinya sebagai Lembaga Penyiaran Publik, di karenakan modal untuk membangun sesuai dengan pasal 14 ayat 1 tentang sumber pembiayaan RRI, TVRI, dan lembaga Penyiaran publik, lokal berasal dari, a) Iuran penyiaran b) Anggaran Pendapatan dan Belanja Negara atau Anggaran Pendapatan Belanja Daerah, c) Sumbangan pendengar, d) Siaran iklan, e) Usaha lain yang sah terkait dengan penyelenggaraan penyiaran.

Penerimaan yang diperoleh dari sumber pembiayaan sebagaiman dimaksud pada ayat (1) pasal 14 huruf a, huruf $b$, huruf c, huruf $d$, huruf e merupakan penerimaan Negara yang dikelolah langsung secara transpran untuk membiayai lembaga penyiaran publik sesuai dengan ketentuan peraturan perundangan-perundangan yang berlaku. ${ }^{6}$ Dengan latar belakang diatas penelis tertarik meneliti LPP RRI Mataram dengan judul:

\footnotetext{
${ }^{6}$ Peraturan Pemerintah Republik Indonesia Nomor 11 Tahun 2005 Tentang Penyelengaraan Lembaga Penyiaran Publik.
} 
Eksistensi LPP RRI Mataram Berdasarkan Teori Niche

\section{Metode Penelitian}

Pada penelitian ini, peneliti menggunakan metode penelitian kualitatif dengan analisis diskriptif. Metode penelitian ini merupakan pengamatan yang bersifat ilmiah yang di lakukan secara hati-hati dan cermat bertujuan menyelsaikan ssuatu peristiwa. $^{7}$ Metode ini menggambarkan eksistensi LPP RRI Mataram, sebagai lembaga penyiaran republik Indonesia yang ada di Kota Mataram.

Teori yang digunakan dalam penelitian ini adalah teori Niche, teori ini muncul dari disiplin Ekologi. Ekologi merupakan konsep sentral penelitian tentang kompetisi antar industri dengan media. Ekologi berkenan dengan hubungan timbal balik antara mahluk hidup dengan lingkungan sekitarnya.

Teori Niche sebenarnya bukanlah teori yang baru. teori ini sudah dikembangkan sejak tahun 1960-an oleh para ahli ekologi seperti S.A. Levins, R. Levins, Ricklefs E.R.pianka dan R. H. Whittaker. Niche dapat diartikan sebegai "ceruk", "relung" atau ruang kehidupan". Fokus pembahasanya adalah mengenai proses, ciri-ciri, hubungan dan inrakaksi antara populasi dalam upaya mempertahankan kehidupanya.

Dimmick dan Rohtenbuhler mencoba menganalogikan fenomena kompetisi antara industri media sebagai suatu proses ekologis.

\footnotetext{
${ }^{7}$ Jualiansyah Noor, Metodologi Penelitian, (Kencana prenada Group), hlm. 35.
}

Dalam pandangannya kompetisi media dapat digambarkan seperti mahluk-mahluk hidup yang harus mempertahankan hidupnya dalam suatu lingkungan (pasar). Bagaimana ia bertahan dan bagaimana makhluk media tersebut mampu mencari-mendapatkan dan merebut sumber makanan yang tersedia dalam lingkungan tersebut. Persoalanya adalah jika sumber makanan yang ada di lingkungan tersebut terbatas. Sementara makhluk hidup yang menggantungkan dirinya kepada sumber tersebut semakin banyak maka faktor kompetisi tidak terelakan.

Anologi di atas dapat digambarkan bahwa pada media sejenis dapat diklasifikasikan sebegai suatu populasi, dan dengan demikian terdapat beberapa populasi yaitu populasi televisi, radio, flim, media cetak (koran, majalah, tabloid) dan sebagainya. Kompetisi terjadi setidaknya pada dua level, yaitu kompetisi antar populasi media dan kompetisi antara anggota populasi tersebut. Jika diamati nampak bahwa kompetisi antara anggota populasi cendrung lebih ketat dari pada antar populasi.

Lewin mengatakan bahwa sifat interaksi antar makhluk hidup yang tinggal di suatu lingkungan, tergantung pada tiga faktor yaitu:

1) Daerah/ruang sumber penunjang kehidupan yang ditempati oleh suatu mahkluk, yang disebut sebegai Niche breadth.

2) Penggunaan sumber penunjang kehidupan yang sama dan terbatas oleh dua atau lebih makhluk hidup, 
sehingga terjadi ketumpangtindihan, yang disebut Niche overlap.

3) Jumlah seluruh penunjang kehidupan yang tersedia bagi seluruh warga populasi.

Dalam teori Niche tersebut di atas, Niche breadth, menunjukan bahwa hubungan antara suatu populasi dengan sumber penunjang kehidupanya dalam suatu lingkungan dapat dipolarisasikan menjadi dua yaitu, jika terdapat ketergantungan yang tinggi terhadap "satu" jenis sumber penunjang hidup, maka populasi/makhluk tersebut disebut sebagai spesialis. Sebaliknya jika sumber penunjang kehidupanya beragam jenis disebut sebegai generalis. Niche overlap, menunjukan derajat ketumpangtindihan-ketergantungan populasi terhadap sumber penunjang hidupnya, yaitu tentang bagaimana makhluk tersebut memiliki kesamaan antara satu dengan lainya terhadap sumber penunjang hidup tersebut.

Teori ini dapat digunakan untuk riset tingkat kompetisi antar media massa, baik surat kabar, radio atau pun televisi. Teori ini juga dapat digunakan untuk mengukur persaingan antar program PR beberapa perusahaan. selanjutnya, kompetisi antar industri media adalah kompetisi untuk memperbutkan sumber penunjang kehidupan. Menurut Dimmick dan Eric Rohtenbuhler mengatakan bahwa sumber penunjang kehidupan media itu ada tiga

a. Pertama, capital, yang meliputi struktur permodalan dan pemasukan iklan. b. Kedua, types of content, yang menunjukan aspek program atau jenis isi media. Faktor konten merupakan deskripsi isi dari media yang bersangkutan.

c. Ketiga, types of audience, yang menujukan jenis pendengar sasaran atau target audien. Faktor audien pada dasarnya dapat dilihat melalui dua yaitu dari asumsi media yang bersangkutan atau penelitian khusus mengetahui frofil pendengar dan kebutuhan konsumsi media mereka.sekaligus sumber"makanan" bagi media agar dapat survive dan mengembangkan dirinya dalam situasi kompetisi yang ketat.

Faktor capital, pada umumnya dilihat melalui iklan yang masuk dalam media tersebut, selain permodalan. Hal tersebut juga menyangkut besaran iklan (misalnya secara nasional) dan bagaimana proporsi yang akan dikonsumsikan oleh berbagai media-dan khususnya yang diperebutkan oleh radio. faktor audience pada dasarnya dapat dilihat melalui dua hal yaitu dari data asumsi/profile media yang bersangkutan atau dari penelitihan khusus untuk mengetahui profile khalayak dan kebutuhan konsumsi media mereka. faktor content merupakan deskripsi isi dari media yang bersangkutan, hal tersebut dapat dilihat dari berb agai rubrikasi/program acara yang ada. $^{8}$

${ }^{8}$ F.Anita Herawati dan Setio Budi HH, "Ekologi Media Radio Siaran di Yogyakarta "Kajian Teori Niche Terhadap Program Acara Radio Siaran di Propinsi Daerah Istimewa 


\section{Pembahasan}

\subsection{Eksistensi LPP RRI Mataram}

Berbicara mengenai eksistensi, secara bahasa berati adanya kehidupan. Adalah keberadaan kehadiran yang mengandung unsur bertahan. Sedangkan eksistensi sendiri seperti yang dikemukakan oleh Abidin Zenal.

Eksistensi adalah suatu proses yang dinamis, suatu menjadi atau mengada. Ini sesuai dengan kata asal eksistensi itu sendiri, yakni exsistere, yang artinya keluar dari, melampaui atau mengatasi. Jadi eksistensi tidak bersifat beku atau berhenti, melainkan lentur dan kenyal dan mengalami perkembangan atau sebaliknya kemunduran tergantung pada kemampuan dalam mengatualisasikan potensi-potensinya. ${ }^{9}$

Dari definisi tersebut dapat dilihat bahwa pada dasarnya LPP RRI Mataram tidak akan mengalami kemunduran, terutama dalam hal keuangan. Hal ini dikarenakan LPP RRI Mataram adalah bagian dari lembaga penyiaran publik yang mendapatkan dana operasional lansung dari pemerintah. Sesuai dengan UU No. 32 tahun 2002 tentang penyiaran pasal 15 , sumber pembiayaan berasal dari iuran penyiaran, APBN atau APBD, sumbangan pendengar, siaran iklan, dan usaha lain yang terkait dengan penyelenggaraan penyiaran yang selalu bertangung jawab terhadap pemerintah. Selain itu LPP RRI Mataram juga selalu

Yogyakarta”, Ilmu Komunikasi, Vol. 4, Nomor 2, Agustus 2019, hlm. 114.

${ }^{9}$ Suryadi, "Pengertian Eksistensi", dalam http://digilib. Unila.ac.id. diakses pada 5 November 2019 mengkordinasikan program kerja dan siaranya ke Komisi Penyiaran Indonesia.

Salah satu cara LPP RRI Mataram untuk lebih dekat dengan pendengarnya yaitu dengan mengadakan acara on air atau of air. Dan ada juga semacam jumpa fans, membentuk forum komunikasi dan forum pemerhati. Inilah salah satu upaya LPP RRI Mataram mengikat pendengarnya.

LPP RRI Mataram menggunakan FM untuk dalam kota dan AM di luar kota atau di pelosok, dan SW untuk keluar negri dan LPP RRI Mataram mengunakan setlit palapa C2 untuk sistem komunikasinya, dan kita bisa mendengarkan LPP RRI Mataram dimana saja, karena LPP RRI Mataram berjaringan nasional. Hingga saat ini LPP RRI Mataram masih tetap eksis, dan memillik pendengar yang setia. Terbukti sampai saat ini bisa dikatakan kalau dalam 1 jam puluhan yang mengirimkan sms dan sekian puluh penelpon menandakan bahwa LPP RRI Mataram masih eksis dan acaranya masih bisa dinikmati dan digemar oleh pendengar. ${ }^{10}$

Hal yang sama juga disampaikan oleh bapak Supardi sebagai informan pendukung selanjutnya yang mewakili elmen pendengar. Saat di temui untuk diwawancara, bapak Supardi mengakui bahwa LPP RRI Mataram masih tetap eksis karena program yang disiarkan oleh LPP RRI Mataram benar-benar mencerminkan NTB yang sesunggunya. Hal tersebut ada beberapa program siaran LPP RRI Mataram yang ia selalu mengikutinya atau

\footnotetext{
${ }^{10} \mathrm{Ni}$ Ketut Sri Ulati, Sebagai Direktur Programa 1 dan Programa 2 Wawancara, 6 Agustus 2019
} 
mendengarkanya. Salah satu acara favoritnya "Renungan Fajar" dengan adanya program tersebut betul-betul menambah wawasan tentang agama islam. Dan masih banyak program LPP RRI Mataram yang lain senang untuk mendengarkanya.

Kemudian syarif yang merupakan pendengar lain dari kalangan remaja menambahkan bahwa LPP RRI Mataram adalah salah satu radio yang memberikan informasi, hiburan, pendidikan yang sehat dan bermanfaat. LPP RRI Mataram cukup bagi sebegai rujukan untuk mendapatkan informasi, hiburan, pendidikan saya lebih mengetahui tentang informasi-informasi yang betul indenpenden dan menggambarkan NTB yang sesunggunya demikan kata syarif.

Dari berapa penuturan informasi pendukung yang dianggap mewakili pengertian eksistensi, maka peneliti dapat katakan bahwa LPP RRI Mataram dapat dikatakan eksis. Dan berapa hal yang menunjang eksistensi tersebut membuktikan bahwa LPP RRI Mataram dapat bertahan dan terus mengembangkan usaha.

\subsection{LPP RRI Mataram berdasarakan Teori}

Niche.

Pada bagian pertama capital, terdapat struktur pemodalan dan pengiklan yang dapat menunjang keberlangsungan hidup LPP RRI Mataram yaitu dari APBN dan APBD karena LPP RRI Mataram merupakan bagian dari pemerintah. Selain itu LPP RRI Mataram memberikan kesempatan kepada istansi-istansi pemerintah untuk bekerja bersama dalam iklan layanan pendengar, LPP RRI Mataram juga terbuka terhadap iklan yang sifatnya komersil dalam artian, jika pendengar mempunyai produk dapat disiarkan di LPP RRI Mataram. Hal ini sesuai dengan visi misi LPP RRI Mataram sebegai pengembang potensi bisnis pendengar.

Pada bagian kedua types of conten, yang menunjukan aspek program atau isi media. Dalam hal ini LPP RRI Mataram mempunyai pengelolahan segmentasi tersendiri yakni Prol dikembangkan untuk pemberdayaan pendengar, dan Pro2 dikembangkan untuk kreatifitas anak muda. Sesuai dengan visi-misi RRI, LPP RRI Mataram terus mencoba meningkatkan kualitas audio dan memperluas jangkuan siaran secara nasioanal dengan mengoftimalkan sumber daya teknologi yang ada seperti audio dan video streaming dan RRI Play, beyong yang berbasis diaplikasi android. LPP RRI Mataram menyelenggarakan siaran informasi, pendidikan, budaya, hiburan, iklan, dan lain sebegainya.Yang tujuannya untuk mencerahkan, memberdayakan, serta mendorong kreatifitas pendengar dalam rangka membangun krakter bangsa, dan memberikan siaran yang dapat menggali, melestarikan, mengembangkan budaya bangsa, memberikan hiburan yang sehat, serta membentuk budi pekerti dan jati diri bangsa ditengah arus glabalisasi.

Pada bagian ke tiga types of audience, yang menunjukan jenis pendengar sasaran atau target audien. LPP RRI Mataram sebegai radio yang telah berkiprah untuk membangun Bumi Gora NTB dan selalu berusaha memberikan pelayan kepada publik dengan terus 
meningkatkan jangkuan siar hingga kepelosok-pelosok Bumi Gora NTB yang belum terjankau oleh media lainya. sesuai dengan segmentasi kanal-kanalnya baik itu Pro1 maupun Pro2.

Penerapan teori Niche pada LPP RRI Mataram dinilai sudah sesuai dengan konsepsi mengenai ekologi media. Hal ini dikarenakan kegiatan penyiaran yang dilakukan oleh LPP RRI Mataram sudah mencakup sumber penunjang kehidupan media baik dari suatu permodalan, audien, maupun konten.

\section{Simpulan}

Berdasarkan penelitian di atas, peneliti dapat menyimpulkan bahwa LPP RRI Mataram dapat tumbuh sekaligus bisa menjaga eksistensinya sebagai lembaga penyiaran publik yang bersifat independen sesuai dengan amanat undang-undang dan tujuan berdirinya LPP RRI Mataram. Berdasarkan teori Niche LPP RRI Mataram dapat bersaing dengan radio swasta yang ada di NTB dan Mataram khususnya dikarenan LPP RRI Mataram dapat memenuhi tiga komponen besar untuk bersaing dengan radio yang ada di Mataram diantaranya, capital, pengiklan yang dapat menunjang keberlangsungan hidup LPP RRI Mataram yaitu dari APBN dan APBD. types of conten, pro1, pro2, dan mengoftimalkan sumber daya teknologi audio dan video streaming dan RRI Play, beyong. types of audience, yaitu seluruh masyarakat NTB.

\section{Daftar Pustaka}

F. Anita Herawati dan Setio Budi HH, "Ekologi Media Radio Siaran di
Yogyakarta "Kajian Teori Niche Terhadap Program Acara Radio Siaran di Propinsi Daerah Istimewa Yogyakarta", Ilmu Komunikasi, Vol. 4, Nomor 2.

Masduki. 2001. Jurnalistik Radio. Yogyakarta: Lkis.

2003. Radio Siaran dan
Demokratisasi, Yogyakarta: Jendelah.

Mufid, Muhamad. 2001. Komunikasi Regulasi \& Penyiaran diterbitkan Atas kerja Sama Dengan UIN Press.

Noor, Jualiansyah. Metodologi Penelitian. Kencana Prenada Group

Suryadi, "Pengertian Eksistensi", dalam http://digilib. Unila.ac.id. diakses pada 5 November 2019 